\title{
An Escape to Imagination
}

Roni Natov. 2018. The Courage to Imagine: The Child Hero in Children's Literature. London/New York: Bloomsbury Academic. 205 pp. ISBN 978-1-4742-2122-1

One of the most prominent characteristics of childhood is usually imagination children's ability to create and form new ideas and emotions. Children are able to create imaginary worlds and fully immerse themselves in them. In her book The Courage to Imagine: The Child Hero in Children's Literature, Roni Natov, Professor of English and literature at Brooklyn College, focuses on this ability, with special emphasis on aspects in which literature can be of special importance. Through the study of several child heroes in children's literature, the author shows how they can help develop empathy, deal with fear and trauma, encourage the acceptance of difference, and challenge social institutions.

The Courage to Imagine is published by Bloomsbury Academic as part of its series Bloomsbury Perspectives on Children's Literature, the aim of which is to expand the scope and quality of literature research. It consists of eight chapters, along with an introduction and an epilogue. Readers become acquainted with the topic in a short contemplation of the importance of imagination, several explanations of it, and ways in which literature contributes to the process of imagining. Each of the chapters that follow is concerned with one of the aspects which can be influenced by reading literature.

The beginning of the book is dedicated to outdoor landscapes dominant in books intended for children and their ability to inspire children's imagination. The author demonstrates how the forest, the sky, and the river can represent states of mind which are characteristic of childhood. They can be wild and dangerous, sometimes even connected with fear, but also friendly and warm, offering comfort and peace. On the other hand, sometimes indoor landscapes have a more important role, because they offer privacy and a sense of security. The second chapter is closely connected with the first in its intention to show how creativity can be constructed and encouraged. It points out that there are many ways in which children can "express and act out their imaginative capacities" (15), with the possibility to recognise them and relate them to examples found in children's books.

The following chapter applies the previously explained ideas to the works of William Steig. We are introduced to Steig's two narratives - Dominic and Abel's Island, which are viewed as representations of art and imagination. Through short summaries of the stories, the author shows how they value artistic expression which can be revealed through painting or playing music. With the help of the summaries, which the author supports with her observations, we can see how the characters develop throughout the stories, but also how their perception of the world changes. With the example of the ending of Abel's Island, which leaves us with questions, this chapter shows how literature can encourage creativity in the reader's mind and provide a new perspective of the world.

The fourth chapter discusses the presence of diversity and difference in children's literature in terms of class, gender, and culture. It presents several narratives, including the picturebook Two Mrs. Gibsons which depicts the life of a child with a Japanese mother and an African American grandmother. It demonstrates how picturebooks also present different states of mind and imagination through their illustrations. While reading a picturebook, 
children observe illustrations and discover their meaning and importance. Some of the other works which are mentioned are In My Family, Owen \& Mzee, American Born Chinese, A Wish After Midnight, and Fun Home. Each has a specific subject, such as living as a member of the Mexican minority in America, being Chinese immigrants or part of an Indian community, but they all share the common idea of imaginative thinking, accepting difference and being proud of the diversities that are present in the world.

The next chapter, "Reimagining Fear and Trauma", deals with topics which are sometimes seen as taboo and shows how literature can help in healing trauma. It is divided into several subchapters which deal with different types of trauma, such as fear, sexual trauma, death, and bullying. This chapter can be of special importance because the characters from the books presented can give readers "hope, a recognition that this terrible thing has happened to others and that they have survived" (58). It is easy for young readers to identify with the characters and to see how they deal with their trauma. The author explores different aspects of fear and trauma in selected books (e.g. The Wolves in the Walls, The Tale of One Bad Rat, The Graveyard Book, A Monster Calls), showing how characters in these books heal and how negative experience changes them and points them in a new direction.

The sixth chapter presents new heroes who represent change in typical childhood. They are often presented as strong, independent, and intelligent. The most famous examples of such characters are Carroll's Alice, Lindgren's Pippi, and Dahl's Matilda, who are sometimes portrayed as smarter than adults. There are many other less-known books which also contain strong heroes. One such hero is Omakayas whose psychological development occurs in The Birchbark House by Louise Erdrich, where she learns to understand her feelings and instincts. King Matt (King Matt the First by Janusz Korczak) and Totto-chan (Totto-chan, the Little Girl at the Window) are also new, unconventional heroes because they question the world and its social institutions (the government and educational system). They encourage readers to think about their own situation and community, which could help them become more involved and respected citizens one day.

The next chapter is concerned with empathy, which is the ability to imagine that we are somebody else in order to feel and understand other people's emotions and worries. It is interesting how novels can increase the reader's awareness of the surrounding world and compare it with the fantasy world. It is typical of young readers to easily identify with characters and their problems. Natov offers two examples which explore the idea of empathy: The Tale of Despereaux and The Miraculous Journey of Edward Tulane. She shows how these books encourage readers to pay no attention to differences and misunderstandings, but to accept others and put themselves in their place, which is an especially important idea that should be communicated to young readers.

The last chapter leads us into the world of new picturebooks which are sometimes unconventional and combine text and illustrations in a different way. We are presented with the works of Shaun Tan, Brian Selznick, and Peter Sis. Their picturebooks usually tell a story through illustrations, but they strongly depend on the accompanying text. However, illustration and text are equally important and complement each other. They therefore require multiple readings and awaken readers' imagination which is involved in the creation of the story. These picturebooks actively engage readers and enable them to fully use their creative potential and imagination. 
The final part of the book is the epilogue entitled "Surviving Childhood", in which the author shares her thoughts on the importance of literature in children's lives. She sees literature as an opportunity to keep memories, relate stories to pleasant times from the past, and imagine things which are unreachable or far away. For these reasons, children should be encouraged to read, which will equip them with the skills necessary to create their own associations with reading and creating their own worlds.

Finally, The Courage to Imagine demonstrates how literature can influence children's thinking and help them cope with the world around them. Dealing with topics present in everyday life, such as ethnic diversity, fear, bullying, or empathy, and offering examples of child heroes who overcome their problems, this book will be engaging to teachers and students, as well as experts in the field of children's literature. Its simple message that through reading children "can escape the adult world and imagine alternatives" (108) should be sufficient incentive for everybody to immerse themselves in reading and to start imagining.

Josipa Hotovec

\section{Walt Disney and the Power of Music}

James Bohn. 2017. Music in Disney's Animated Features: Snow White and the Seven Dwarfs to The Jungle Book. Jackson, Mississippi: University Press of Mississippi, 294 pp. ISBN 978-1-4968-1214-8

DOI: 10.21066/carcl.libri.2018-07(01).0008

"The essence of a Disney animated feature is not drawn by pencil [...]. Rather, it is written in notes", states James Bohn in the conclusion to his 2017 book Music in Disney's Animated Features: Snow White and the Seven Dwarfs to The Jungle Book (201). Published by the University Press of Mississippi with a forward written by director, producer, and writer Jeff Kurtti, the book gives profound insight into the Disney music legacy. With the exception of Fantasia (1940), which has been omitted since it does not contain original musical material, Bohn's monograph presents all the important musical scores produced by the Walt Disney Studios during Walt Disney's lifetime, from shorts about Mickey Mouse to The Sword in the Stone (1963) and The Jungle Book (1967).

The nine chapters which chronologically follow the creation of Disney's animated films gradually establish a recognisable scheme. Each chapter provides general information about the movie in question, for instance when the rights to the book (if any) were secured, how the idea was originated and developed, who was considered to write the music and songs, etc. Bohn then presents the life and work of one of Disney's composers. Providing interesting insights, the author explains that the first Disney composers mostly did not come from the highbrow world of classical music (which was the case in classical Hollywood liveaction films from the same period); instead, Disney leaned on men who knew something or little about music - some of them were animators (like Wilfred Jackson), some of them were music performers who had never considered composing for the movies before they met Disney (such as Carl Stalling or Frank Churchill). Educated musicians, such as Leigh Harline, Paul J. Smith, or Edward Plumb, joined Disney much later and were mostly used as orchestrators and arrangers, while the actual task of composing was left to the skilled 